\title{
Рецензії
}

\section{Енциклопедія сучасних бріологічних знань}

\author{
Bryophyte Biology. / [edited by] Bernard Goffinet \& A. Jonathan Shaw.- 2nd ed. \\ Cambridge: Cambridge University Press, 2009. - 565 p.
}

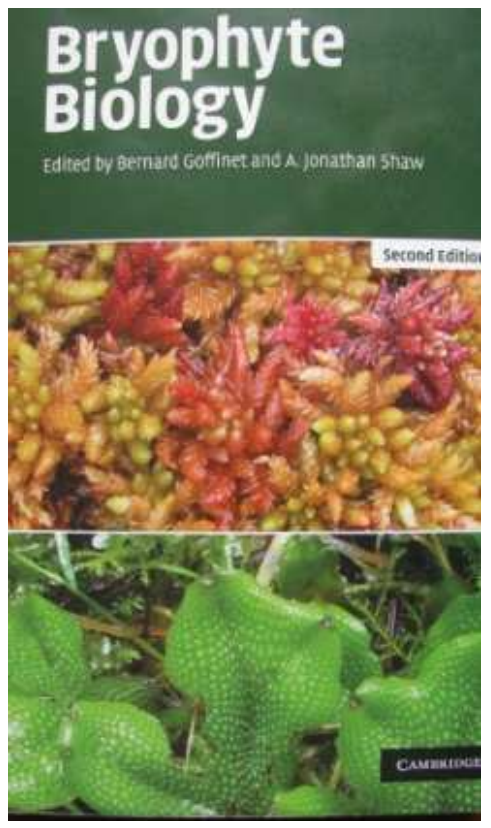

Недавно я отримав книгу «Bryophyte Biology», яку мені люб'язно надіслав Bernard Goffinet, професор екології і еволюційної біології Коннектикутського університету США в обмін на «Чекліст мохоподібних України». Цій дуже корисній для усіх сторін справі посприяли науковці: B.M.Вірченко (Інститут ботаніки, Київ, Україна), R.Ochyra (Інститут ботаніки, Краків, Польща) та William R. Buck (Нью-Йоркський ботанічний сад, США), за що я їм щиро вдячний. Забігаючи наперед, необхідно відзначити, що це дуже цінна праця, це значне, помітне явище у розвитку не тільки бріології, а й фітобіології у цілому. Це енциклопедія сучасних бріологічних знань. Без перебільшення можна сказати, що у цій праці висвітлюються усі найголовніші досягнення у вивченні бріофітів, особливо за останні роки. Авторами кожного розділу були використані усі найважливіші наукові праці, в яких висвітлені результати досліджень бріофітів останнього часу, та інші важливі більш давні бріологічні праці. Дійсно, наприкінці XX, а особливо на початку XXI ст. відбуваються революційні зміни у підходах до вивчення мохоподібних. Це перш за все інтенсивне вивчення закономірностей розташування нуклеотидних пар у ДНК пластидного та ядерного геномів клітин мохоподібних. Результати секвенування (секвенс, секвенування (з англ.) sequence ('si:kwəns - послідовність; ряд; порядок) бріофітів, знання про виникнення мохоподібних, про розвиток мохоподібних у часі та просторі та про реакції мохоподібних на умови навколишнього середовища дають багато матеріалів для висновків та планування напрямків майбутніх досліджень не тільки власне щодо бріофітів, а й щодо походження, еволюії та філогенії усього рослинного світу.

Праця складається з 12 розділів, авторами яких є провідні вчені-бріологи світу. Зрозуміло, що дати повну характеристику у даній публікації неможливо, тому ми приділили більше уваги матеріалам філогенії, класифікації, результатам секвенування та деяким іншим, які можуть стати в пригоді як науковцям, так і викладачам та студентам-біологам.

\section{1. «Морфологія і класифікація Marchantiophyta».}

Barbara Crandall-Stotler, Raymond E. Stotler and David G. Long (Southern Illinois University, USA).

Автори за сучасними даними вказують, що цей відділ включає 391 рід з майже 5000 видів, які поширені на усіх континентах, але найбільше їх зростає у гірських дощових лісах південної півкулі. Підкреслюється, що печіночники споріднені 3 усіма нинішними рослинами, викопні спори, що дуже схожі на спори печіночників, датуються 475 млн. років. Вказується, що при врахуванні цих матеріалів та молекулярних даних виникнення печіночників можна датувати ордовіком, а вік усіх головних предків - пермським періодом, тобто їх геологічний вік значно збільшено. Автори вказують, що на основі палеонтологічних даних та даних молекулярних філогенетичних досліджень одну 3 клад, до складу якої входять родини Haplomitriaceae та Treubiaceae, визнано як предкову для усіх печіночників i виділено в окремий клас - Haplomitriopsida. При цьому вони стверджують, що печіночники за даними сучасних досліджень в цілому вважаються монофілетиками. У розділі подано конспект морфології печіночників 3 врахуванням головних родовідних ліній (клад), вивчених лише недавно, охарактеризовано апікальні клітини і ріст гаметофіта, олійні тільця, 
організацію гаметофіта - варіації морфології листків, простих сланевих та складних сланевих печіночників, спорофіти та асоційовані структури, проростання спор. Схема класифікації печіночників, що подана в розділі, грунтується на морфологічних даних та матеріалах сучасних філогенетичених досліджень. Усі ці праці процитовані у списку використаних джерел. У схемі усі печіночними об'єднані в одну філу - Phylum Matrchantiophyta (однак, -ophyta, це закінчення відділу - divisio). Філа розділена на класи, підкласи, порядки, підпорядки, родини. Для кожної родини вказуються роди, що входять до iii складу. Подаються короткі діагнози надродинних таксонів, крім філи. Виділяються: Клас 1. Haplomitriopsida 3 підкласами Treubiidae та Haplomitriidae; 2. Клас Marchantiopsida 3 підкласами Blasiidae та Marchantiidae; 3. Клас Jungermanniopsida 3 підкласами Pelliidae, Metzgeriidae та Jungermanniidae. Автори стверджують, що дана схема класифікації інтегрує морфологію з новими гіпотезами, отриманими при використанні молекулярного аналізу. Але вони певні того, що вирішення питань філогенії печіночників все ще знаходиться на стадії дослідження, оскільки для молекулярного аналізу використано менше $32 \%$ родів (менше 5\% видів). Вказується, наприклад, що у Marchantiidae викликає сумніви гілка порядка Sphaerocarpales, не вирішені ієрархічні відношення низки родин кронової групи Marchantiales, тобто при появі нових онтогенетичних, ультраструктурних і молекулярних даних, ця схема буде перероблятися.

\section{2. «Морфологія, анатомія і класифікація Bryophyta».}

Bernard Goffinet, William R. Buck and A. Jonathan Shaw (University of Connecticut, USA; New York Botanical Garden, USA; Duke University, Durham, USA).

За сучасними даними автори вказують, що бріофіти нараховують близько 13000 видів мохів і за кількістю видів займають друге місце серед наземних рослин. Вони підкреслюють, що у зв'язку з фертилізацією спорофіт мохоподібних розвивається у вісь без гілок, що несе спороносну коробочку. Автори використали усі публікації останнього часу, у яких відображені недавні філогенетичні реконструкції, які вказують на три споріднені групи перших наземних рослин, що складають еволюційний рівень, який охоплює вихід рослин 3 водного середовища на суходіл. На думку авторів, мохи розвиваються від спільного предка 3 печіночниками i, очевидно, займають проміжне положення, яке передувало розходженню предків на антоцеротофіти та судинні рослини. Наголошується, що висновки, зроблені на основі даних послідовностей у хлоропластах допускають, що вихід на суходіл відбувся 425490 млн. років тому, в силурі або в ордовіку, це підтверджують також фосилізовані мікроорганізми. Проте наводять і іншу оцінку, що базується на даних секвенсу, яка, навпаки, припускає, що сухопутна флора виникла близько 1 млрд. років тому, а дивергенція між мохами і поліспорангіофітами відбулася близько 700 млн. років тому. За цей час предкові форми мохів зазнали численних радіацій, що привело до широкого спектру морфологічного, онтогенетичного, анатомічного та цитологічного різноманіття - більшість сучасних порядків і навіть багато родин виникли у крейдовому періоді.

У даному розділі охарактеризовано також модулярну архітектуру тіла вегетативної рослини, органографію гаметофіта - ризоїди, стебло, модифікацію стебла, листки, охарактеризовано галуження мохів, статеві органи, розподіл, розвиток та розкривання коробочок зі спорами, нестатеве розмноження, компоненти спорофіта: ранній ембріогенез, спорофітну плаценту, захист ембріона, що розвивається, будову зрілого спорофіта, спорогенез і спори, також основні типи перистома та розсіювання спор, ранній розвиток гаметофіта, апогамію і апоспорію: життєвий цикл без статевого процесу і мейозу.

Автори підкреслюють, що морфологічна еволюція бріофітів - це не єдиний напрямок, тобто полярності ознак ранніх трансформацій зворотні (зворотня еволюція широко поширена у мохів і може бути пов'язана зі змінами місцезростань): набутий стан може бути втрачено (наприклад, втрата жилки листка, папіл, продихів, перистома або кришечки та ін.). Як вважають автори, це дуже заважає вивченню філогенетичної 
спорідненості на основі морфології, проблема ускладнюється можливістю того, що навіть такі складні ознаки, як наявність перистома, можуть бути досягнуті знову.

Щодо класифікації бріофітів, то автори розділу вказують, що ще з часів Флейшера та Бротеруса вона постійно переглядається, особливо у світлі філогенетичних висновків. Найсвіжіша ревізія, проведена авторами цього розділу, базується на результатах філогенетичних реконструкцій. Вони пояснюють, що у цій класифікації прийнято ранг надкласу для того, щоб об'єднати усі артродонтові мохи в один таксон (Надклас V). Філогенетична гіпотеза передбачає історію еволюції, коли може бути реконструйовано характер трансформації. Хоча багато уваги приділялося реконструкції відносин між предками мохів, включаючи використання морфологічних ознак, ще не було зроблено критичної або ясної спроби установити філогенетичні ознаки характеру трансформації. Автори підкреслюють, що передчасно пропонувати значні зміни всередині плеврокарпних мохів, оскільки ще мало рішень для розмежування основних клад i ще мало даних секвенування для багатьох родів. В поданій класифікації мохів клада Bryophyta розділяється на 5 надкласів. Перші 4 надкласи включають по 1 класу і лише 5-й надклас включає 5 класів. В надкласі I - клас Takakiopsida 3 одним родом Takakia, в надкласі II - клас Sphagnopsida $з$ родами Sphagnum і Ambuchanania, в надкласі III - клас Andreaeopsida 3 родами Acroschisma i Andreaea, в надкласі IV - клас Andreaeobryopsida 3 одним родом Andreaeobryum. Надклас V об'єднує 4 класи: клас Oedipodiopsida з одним родом Oedipodium, клас Polytrichopsida 324 родами, клас Tetraphidopsida з родами Tetraphis і Tetradontium та клас Bryopsida. Останній клас розділений на підкласи: Buxbaumiidae з родом Buxbaumia, Diphysciidae 3 родом Diphyscium, Timmiidae 3 родом Timmia, Funariidae - 325 родами, Dicraniidae - з родами 24 родин верхоплідних мохів та підклас Bryidae. У цьому підкласі виділються два надпорядки: Bryanae з родами 17 родин верхоплідних мохів та Hypnanae - 3 родами 54 родин бокоплідних мохів.

Як бачимо, в даній класифікації багато проміжних таксономічних одиниць надклас, підклас, надпорядок. Це свідчить про певну тимчасовість цієї класифікації, можливо про недостатню обгрунтованість таксонів, про іiі перехідний характер. Як підкреслюють автори, класифікація буде уточнюватися і перероблятися по мірі накопичення матеріалів секвенування. Однак, на наш погляд, сьогодні вона дає багато матеріалів для збудження бріологічної думки.

\section{3. «Нове розуміння морфології, анатомії і систематики Anthocerotophyta».}

Karen S. Renzaglia, Juan C. Villarreal and R. Joel Duff (Southern Illinois University, USA; University of Connecticut, USA; University of Akron, USA)

У розділі наголошується, що до сих пір антоцеротофіти не викликали до себе великої уваги дослідників, тому навіть їх різноманіття та взаємовідносини усередині групи залишалися не зовсім ясними. Проте антоцеротофіти, яких автори нараховують близько 150 видів, є ключовими предками в розплутуванні етапів розвитку наземних рослин, оскільки дані сучасної молекулярної філогенії вказують, що антоцеротофіти $\epsilon$ найближчими родичами трахеофітів, які збереглися донині. Автори показують, що у морфологічному плані для антоцеротофітів характерні численні особливості структури і розвитку, яких немає у жодного представника сучасних чи викопних архегоніат. В останні 5 років після виходу в світ першого видання книги «Bryophyte bryology (2004)» авторами та іншими дослідниками були глибоко переглянуті усі аспекти еволюції антоцеротофітів. Для цього були використані матеріали мультигенного секвенсу, на основі яких була заснована філогенетична гіпотеза та з'явилися нові схеми класифікації. Завдання, яке поставили автори даного розділу синтезувати нові дані та використати їх для нового розуміння структури, філогенії та класифікації антоцеротофітів, яких зараз нараховується 14 родів. Отримані нові матеріали інноваційної морфології забезпечили більш чітку картину трансформацій всередині групи. Автори підкреслюють, що антоцеротофіти унікальні серед ембріофітів за ключовими морфогенетичними ознаками, оскільки діагностичні морфологічні риси групи включають 
структуру хлоропласта, ендогенний антеридій, деталі організуючого центра мікротрубочки під час мітозу, будову статевої клітини, ріст спорофіта з базальної меристеми, клітини плацентного переносу обмежені лише гаметофітним поколінням, несинхронізований спорогенез. Звертається увага, що разючим контрастом антоцеротових, порівняно з мохами і печіночниками, є невелика кількість зовнішніх відростків - немає листків, лусок, слизистих папіл або поверхневих гаметангіїв, статеві органи і колонії Nostoc заглиблені в слань і в слизисті канали, клітини інтегровані в недиференційовану хлоронему слані. Автори припускають, що маленький розмір, швидкий життєвий цикл, внутрішня секвестрація структур та слизиста проліферація можуть бути ключем до розгадки стійкості цього відносно ізольованого таксона протягом тисячоліть. У поданій авторами класифікації філа Anthocerotophyta розділена на два класи. Клас Leiosporocerotopsida 3 одним родом Leiosporoceros та клас Anthocerotopsida 3 підкласами: Anthocerotidae - 3 родами Anthoceros, Sphaerosporoceros, Folioceros, Notothylatidae - 3 родами Notothylas, Phaeoceros, Paraphymatoceros, Hattorioceros, Mesoceros, Dendrocerotidae - Phymatoceros, Dendroceros, Megaceros, Nothoceros, Phaeomegaceros. Автори обгунтовують, що зрозуміти стратегії та успіхи антоцеротофітів у ранній колонізації суходолу можна лише при безперервному дослідженні ультраструктур, морфогенезу, фізіології, біохімії і філогенії цієї зникаючої групи рослинного світу.

\section{4. Філогеноміка і еволюція давніх наземних рослин.}

Brent D.Mishler and Dean G. Kelch (University of California, USA; CDA Herbarium, Sacramento, USA)

Автори розділу наголошують, що нині настала ера вивчення послідовності нуклеотидних пар усього генома, молекулярні дані стають доступними на такому рівні, який навіть не передбачали кілька років тому, адже кількість повністю досліджених послідовностей геномів ядра і органел зростає, а це дає можливість перейти від простої порівняльної геноміки, обмеженої парними порівняннями геномів, які базувалися на простих співпадіннях послідовностей, до використання багатовидового філогенетичного підходу для аналізу великих наборів геномів. Підкреслюється, що синтез філогенетичної систематики і молекулярної біології (геноміки) - двох колись різних сфер - це початок формування нової сфери, яку Eisen (1998) назвав «філогеномікою», а філогеноміка дає можливість замість використання схожості парних послідовностей використовувати філогенетичні порівняльні методи для підтвердження та встановлення функції гена і взаємодії зразу багатьох геномів. Як указують автори, крос-геномні філогенетичні підходи мають потенціал для розуміння багатьох відкритих функціональних питань, наприклад, процесів, що лежать в основі геномної еволюції, складних взаємовідношень між фенотипом та змінами генома, еволюції складних фізіологічних шляхів у споріднених організмів, а використання такого порівняльного підходу допоможе пояснити, як ці гени взаємодіють у виконанні специфічних біологічних процесів. Тому, на думку авторів, нові порівняльні геномні дані повинні збільшити точність реконструкції Дерева Життя.

Але при тому, що порівняння послідовностей нуклеотидів стало «робочою конячкою» філогенетичного аналізу на всіх рівнях, автори застерігають про те, що $є$ філогенетичні проблеми, які важко розв'язувати за матеріалами секвенування ДНК: це фундаментальні відносини головних груп бріофітів, відносини всередині цих груп, таких як швидка радіація плеврокарпних мохів і листостеблових печіночників та ін. Автори підкреслюють, що метою цього розділу є дослідження взаємовідношення між геномікою і філогенетикою у наземних рослин (особливо бріофітів, оскільки вони є основними предками наземних рослин і дуже важливі для порівняльної геноміки) в двох напрямках - тобто використовувати особливості геномів при філогенетичному аналізі та використовувати філогенію при функціональному аналізі генів. Загальновідомо, що зараз повністю секвенованим є геном лише одного виду мохів - Physcomitrella patens, його повний ланцюжок в DOE Joint Genome BROWSER доступний в Інтернеті http://genome.jgi- 
psf.org/Physcomitrella, а також розпочато роботи 3 повного секвенування печіночника Marchantia polymorpha. Автори розділу впевнені, що геноми бріофітів дадуть інформацію для біоінформативного порівняння і для геноміки рослин. Дослідники нині говорять про «цілогеномний філогенетичний аналіз», тобто про використання знань про розташування нуклеотидів усіх генів у геномі. Автори ж доповнюють, що цілогеномний філогенетичний аналіз реально повинен брати до уваги всю доступну структурну інформацію про геном додатково до змін нуклеотидів, адже прогрес на рівні геномного аналізу приведе до нової ери у філогенетиці рослин. Однак, автори застерігають, що треба бути обережними відносно надмірної довіри до будь-яких даних, у тому числі і до послідовностей ДНК і до структури генома.

\section{5. Мохи як модельні організми для молекулярної і клітинної біології та біології розвитку.}

Andrew C.Cuming (Leeds University, UK)

На початку розділу автор іронічно висловився на адресу модних біологів розвитку рослин, чиї арабідоцентричні погляди на царство рослин ігнорували будь-який інший організм, як поза покритонасінними, так і усередині їх. Але зараз розуміння еволюції функцій гена та ролі генів у програмуванні переходів розвитку, відомих під назвою «ЕvoDevo», вимагає порівняльного аналізу видів, що представляють широкий спектр різних таксонів. Автор вказує, що це співпало з вибуховим характером отримання молекулярних знань, зокрема на прикладі моху Physcomitrella patens, дослідження якого при цьому сприяло вивченню повної послідовності його генома і зараз до цього виду мохів та до мохів, як групи рослин зі своїми унікальними рисами, проявляється великий інтерес. Автор високо цінує мохи як модельні організми, адже це - багата видами група, відомо багато викопних представників ранньої групи наземних рослин, на їх прикладі можна дослідити пристосування, необхідні для завоювання суходолу, вони $\epsilon$ стійкими до стресів у навколишньому середовищі. Далі автор описує проблеми, що лежать перед дослідниками, які мають намір скористатися ресурсами повністю секвенованого геному Physcomitrella. Biн характеризує Physcomitrella patens як модель XXI століття, іï життєвий цикл і розвиток, послідовність генома, відкриття гомологічної рекомбінації, гомологічну рекомбінацію і відновлення ДНК, вимоги до ефективного знаходження гена - довжину і будову, доставку ДНК, ідентифікацію генних мутацій, підтвердження, що мутація викликає мутаційний фенотип, аналіз мультигенної родини тощо.

При характеристиці транскрипційних мереж автор показує, що порівняльний аналіз різних таксонів, включаючи мохи, демонструє, як вибірково використовувалися різні групи транскрипційних факторів, наприклад, еволюція стійкості до висихання. Феномен ангідробіозу поширений у природі. У рослин, зокрема у бріофітів - це давня риса, дуже важлива для завоювання суходолу колишніми водними організмами, у трахеофітів властивість стійкості до висихання була втрачена вегетативними тканинами, але збереглася еволюційним процесом у репродуктивних пропагулах - насінні і спорах. Далі автор аналізує останні наукові досягнення - зараз можна визначити набір генів, що контролюють витривалість до висихання, це складний набір, що кодує т.з. «останні ембріогенезні» протеїни. Ці гени $є$ у водоростей, насінних рослин, у тварин, що вказує на їх раннє походження. У мохів і квіткових рослин використовується один і той же транскрипційний активаційний механізм, але у останніх транскрипційна мережа стала ізольованою до останніх етапів розвитку насіння. На основі цього автор вказує, що виникнення цієї родини генів датується часом ще докембрійського «вибухового» видоутворення.

Наприкінці даного розділу автор резюмує, що використання біоінформаційних інструментів для гарантії порівняльного геномного аналізу генів, що мають відношення до розвитку Arabidopsis та легкість, з якою може бути проведений функціональний аналіз їх двійників у Physcomitrella, показує цінність застосування «молекулярної бріології» в досягненні більш повного розуміння стратегій еволюції рослин взагалі. 
6. Фізіологічна екологія.

Michael C.F.Proctor (University of Exeter, UK)

Підсумовано вивчення фізіології та екології бріофітів в порівнянні з судинними рослинами. Автор у вступі до розділу нагадав відомі істини щодо бріофітів для того, щоб показати на них закономірності їх фізіологічної екології. Він підкреслив, що тіла бріофітів, як правило, на два порядки менші за судинні рослини, і ця різниця дуже впливає на їх фізіології. Далі автор показує різницю між бріофітами і судинними рослинами у цьому сенсі: наприклад, гравітація є основним обмежуючим фактором для дерев, але для бріофітів не $\epsilon$ такою; бріофіти взагалі мають більшу поверхню для випаровування пропорційно до маси рослини, ніж судинні рослини. Масштабні відміни у відношенні бріофітів і судинних рослин до їх атмосферного оточення: листки судинних рослин типово розвернуті в турбулентному повітрі над землею; опір дифузії тонкого пограничного шару малий, тому епідерміс 3 кутикулою і продихами відмічають межу між відносно повільною дифузною масою переносу усередині листка і набагато швидшим турбулентним потоком в оточуючому повітрі; маленькі листки багатьох бріофітів повністю знаходяться всередині шаруватого бріофітного покриву або подушки чи субстрату, на якому вони ростуть. Автор підкреслює, що 3 цих причин важливо підходити до фізіології бріофітів 3 клітинно-біологічних та фізичних принципів, оскільки концепції, що стосуються фізіології судинних рослин, не придатні для бріофітів.

Далі автор продовжив порівняння бріофітів і судинних рослин в екологофізіологічному аспекті: бріофіти порівняно з судинними рослинами мають альтернативну стратегію, яка дозволяє втрату води (пойкілогідрія є дуже ефективною для дрібних рослин), вони витривалі до пересихання, фотосинтезують і ростуть під час вологих періодів, призупиняють метаболізм під час посухи, їх пойкілогідрія означає, що вони можуть поселятися на непридатних для існування судинних рослин поверхнях - стовбурах дерев, відслоненнях скель тощо; бріофіти всмоктують воду і поживні речовини всією поверхнею пагонів з дощової води, крапель туману і хмар, повітряного пилу, і ця здатність $є$ основою для їх успішного поселення у місцях з обмеженим живленням, але при цьому бути вразливими при забрудненні повітря.

Нагадавши, що дивергенція бріофітів і різних груп судинних рослин відбулася в період ранньої історії життя рослин на суходолі (400 млн. років тому і навіть більше) - мохи, печіночники, антоцероти розвивалися незалежно доволі довго, автор наголошує, що фізіологічно бріофіти не прості, не примітивні, їх треба розглядати не як примітивних предків судинних рослин, а як інших високо розвинутих представників альтернативної стратегії адаптації, адже вони домінують у рослинному покриві субполярних, альпійських територій, тундри, боліт, нижніх ярусів лісів від бореальної зони до мохових лісів тропічних гір, де конкурують лише з лишайниками.

Автор розглядає у розділі екофізіологічні особливості, характерні саме для бріофітів, їх відношення до вологи, перенесення висихання, пагони бріофітів як фотосинтетичні системи (усі бріофіти - рослини С3), серед них унікальними $є$ антоцеротові, оскільки вони мають механізм концентрування вуглецю. В кінці розділу автор нагадує, що бріофіти філогенетично різноманітні, мохи, печіночники, антоцеротові - були еволюційно незалежні один від одного і від судинних рослин протягом більшої частини історії рослин на землі. До цього можна внести доповнення, що і тепер вони також незалежні.

\section{7. Біохімічні і молекулярні механізми витривалості до висихання у бріофітів.}

Melvin J. Oliver (University of Missouri, USA)

У даному розділі автор з філогенетичних позицій розглядає механізми витривалості до висихання. Бріофіти, як одні з найдавніших наземних рослин, займають важливе місце в дослідженнях виникнення і існування механізмів, за допомогою яких рослина відповідає на дегідратацію. Можливо, припускає автор розділу, що механізми, за допомогою яких бріофіти переживають дегідратацію, відображають способи подолання жорстких умов сухої 
атмосфери, які використовували перші наземні рослини при колонізації суходолу, адже вегетативна витривалість до пересихання у наземних умовах була необхідна при переході рослин з водного середовища на суходіл, а перші рослини мали дуже просту будову i повинні були розвивати складні стратегії для збереження води. Автор наводить пояснення, що для того, щоб вижити такі рослини повинні були виробити вегетативну виносливість до пересихання. Вона спочатку виробилась у спор як засіб розселення, адже спори мають малий водний потенціал і використовують цей простий механізм для виживання в сухий період. Як підкреслює автор, бріофіти, предки яких ознаменували вихід на сушу і таким чином були ініціальною ланкою у філогенетичному розвитку наземних рослин трахеофітів, дають унікальну можливість дослідити механізми витривалості до пересихання вегетативної сфери, яка прямо розвинулася на ранніх етапах еволюції наземних рослин.

У розділі розглядаються питання щодо загальних аспектів перенесення висихання відносно до бріофітів, біохімічні і молекулярні аспекти - складові молекулярного захисту бріофітів, шляхи прибирання реактивного кисню, штучно викликане перенесення висихання у бріофітів, біохімічні і молекулярні аспекти відновлення та геномний підхід до цієї проблеми. На думку автора, геномний підхід до розуміння найскладнішої риси витривалості рослин до пересихання - пропонує багато шляхів каталогізації тих генів, продукти яких відігрють певну роль у відповіді бріофітів на пересихання та регідратацію. Як завдання, автор вказує, що треба досягти розуміння, які гени адаптивні і центральні у процесах висихання і регідратації у видів, ключових у філогенії усіх наземних рослин. Порівняння з використанням бріофітних моделей будуть неоціненні в цьому процесі і будуть підтримувати еволюційні висновки з цих досліджень.

В кінцевих коментарях до розділу автор вказує, що у цій проблемі є більше запитань, ніж відповідей. Цілком згоджуємося з автором, що цілісна картина витривалості бріофітів до висихання все ще перебуває у своєму зачатковому періоді.

\section{8. Мінеральне живлення та екологія субстратів.}

Jeff W.Bates (Imperial College at Silwood, Berkshire, UK)

Порівнюючи бріофіти з судинними рослинами, автор розділу вказує, що за основними вимогами до мінеральних поживних речовин і мікроелементів бріофіти мало чим відрізняються від судинних рослин та водоростей, однак від судинних рослин вони дуже відрізняються шляхами надходження поживних речовин і це інколи має дуже важливі наслідки для екосистем, в яких вони зростають, адже завдяки особливим режимам отримання поживних речовин бріофіти часто акумулюють хімікати до концентрацій, що набагато перевищують ті, які є в навколишньому середовищі, що використовується зараз при проведенні методу бріомоніторингу. Далі в розділі дано опис особливих проблем, 3 якими стикаються бріофіти при отриманні істотних мінеральних поживних речовин і при взаємодії з неістотними елементами і їх складовими. Нині відомо більше про опади та використання азоту бріофітами, тому в даному розділі зосереджено увагу на мінеральному живленні і екології субстратів. Субстрат, на якому росте бріофіт, може бути як джерелом поживних речовин, так і інших хімікатів, які можуть викликати стрес. Автор попереджає, що треба розмежувати назву «субстрат», яка використовується для назви субстанції, на якій відбуваються ензимні або біохімічні процеси і назву «субстрат», що використовується для назви поверхні з рослинами або лишайниками.

Даний розділ ділиться на два підрозділи. У першому підрозділі «Мінеральне живлення» автором дано характеристику процесів клітинного живлення, вимоги до живлення мінеральними речовинами, поглинання бріофітами мінеральних речовин усією сланню, надходження поживних речовин у природі, ефект висихання на утримання поживних речовин сланню, очевидність внутрішнього перетворення поживних речовин, роль бріофітів у динаміці поживних речовин в екосистемі, явище нестачі і надлишку поживних речовин, біомоніторинг мінеральних відкладів. У другому підрозділі «Екологія субстратів» охарактеризовано екологічні особливості субстратів, довговічність та хімічну 
характеристику субстратів, дано ранжирування субстратів, на яких поселяються мохоподібні, характеризуються епіфіти, епіфіли, епіліти, епіксили, мохи горілих місць, мохи на екскрементах, кальцефіли та кальцефоби, галофіти, металофіти.

\section{9. Структури і функція торфовищ, в яких переважають мохи.}

Dale H.Vitt and R. Kelman Wieder (Southern Illinois University, USA; Villanova University, USA)

На фоні загальної характеристики торфовищ автори відзначають особливості мохоподібних та судинних рослин, які пов'язані з торфовищами. Вони вказують, що торфовища - це незбалансовані екосистеми, в яких ріст рослин перевищує розпад органічних решток, тому на торфовищах за довгий період часу - за тисячоліття збирається значна кількість органіки, або торфу, який складається з фрагментів рослин, що зростали на поверхні торфовища і які повністю не розклалися. Автори пояснюють, що розклад рослин відбувається під дією мікроорганізмів, які утилізують мертві рослини як джерело вуглецю для дихання як у верхньому - аеробному шарі, так і у нижньому - анаеробному шарі торфу, при цьому нестійка частина клітини, целюлоза і геміцелюлоза є більш доступними джерелами вуглецю, ніж стійкі до розкладу лігнінові суміші, залишки яких сконцентрувалися у торфі. Підкреслюється, що судинні рослини - дерева, кущі, трави торфовищ, в яких переважають мохи, дають менше біомаси і розкладаються більше, ніж наземний моховий покрив. Автори відзначають, що поверхня торфовищ у північних районах планети майже завжди повністю вкрита моховим покривом, більша частина біомаси якого складається 3 матеріалів стінок клітин, що повільно розкладаються, а таке повільне розкладання просоченого водою торфу в анаеробних умовах, 3 прохолодним кліматом i прохолодним вологим сезоном, сприяє росту бріофітів та накопиченню органіки на великих площах, причому у північних торфовищах торф складається переважно з залишків бріофітів.

У розділі досить детально охарактеризовано типи і структуру торфовищ, їх гідрологію, хімію, флору і рослинність, функції та екологічну значимість мохового покриву, поглинання поживних речовин та наслідки атмосферних опадів, здатність утримувати вологу, розкладання, ацидофікацію, відповіді на зміни в навколишньому середовищі, вплив на торфовища та на мохи розмерзання мерзлоти, пожеж, кліматичних циклів.

\section{0. Екологія популяцій та угруповань бріофітів.}

Hakan Rydin (Uppsala University, Sveden)

У розділі вказується, що сучані підручники з загальної екології містять дуже мало або й взагалі не містять прикладів бріофітів як зразків динаміки популяцій і метапопуляцій, розсіювання, конкуренції, змін травоїдних, багатства видів. Автор ставить риторичне питання - чи можна легко адаптувати теорії, які грунтуються на вивченні судинних рослин або тварин, і застосувати їх до бріофітів. Звичайно, що ні. В цьому розділі подано приклади популяційних процесів і процесів в угрупованнях, що грунтуються на вивченні бріофітів, розглядається їх історія, морфологія і фізіологія, що може допомогти зрозуміти динаміку популяцій, різноманіття угруповань, видовий склад.

Підкреслюється, що бріофіти мають велике значення у багатьох місцезростаннях, вони важливі для функціонування екосистем, особливо такі мохи, як сфагнові, оскільки кількість вуглецю у сфагновому торфі північної півкулі становить близько 44\% всього диоксиду карбону атмосфери; у цих північних широтах мохи займають значне місце у біорізноманітті багатьох екосистем північних широт. Як приклад, автори наводять Швецію 0,8\% видів судинних рослин всього світу і 7,5\% бріофітів. Можна додати ще для прикладу і Україну, розташовану у помірних широтах, тут також спостерігається така ж закономірність - 1,9\% видів судинних рослин всього світу і 5,9\% бріофітів. Автори вбачають перевагу у використанні бріофітів як модельних організмів в популяційних і фітосоціологічних дослідженнях в тому, що багато видів, особливо домінантних, мають дуже широкі ареали, $\mathrm{i}$ попереджають, що при інтерпретації процесів в популяціях і угрупованнях необхідно брати до уваги, що бріофіти, як це загальновідомо, значно відрізняються у морфологічному, 
фізіологічному i історико-філогенетичному відношенні: у них проста морфологія за відсутності коренів, продихів, а у більшості видів - провідних тканин та наявність особливого життєвого циклу; більшість бріофітів модулярні і клональні, це має низку екологічних наслідків; особливо важлива їх здатність до регенерації з фрагмента будь-якої частини гаметофіта, зі спеціальних нестатевих пропагул, які утворюють багато видів печіночників i акрокарпних мохів; вони здатні переносити несприятливі умови місцезростань завдяки значній фенотипічній пластичності морфологічних і фізіологічних властивостей; дводомність набагато частіша у бріофітів, ніж у судинних рослин. Крім того, порівнюючи судинні рослини і бріофіти для популяційних досліджень, автор вказує, що тварини під час випасу, гриби-паразити та мікориза дуже впливають на судинні рослини i мало впливають на бріофіти. Внаслідок низької поживності, або особливої біохімії, тварини в цілому уникають бріофітів.

У розділі описані популяційні процеси - спорова продукція, ціна розмноження, розсіювання, схожість і відновлення, банки діаспор, клональна експансія і стабільність популяцій, залежність від щільності в популяціях бріофітів, дослідження динаміки популяцій моху Hylocomium splendens за допомогою матричної моделі. Характеристика метапопуляцій бріофітів, метапопуляційних процесів подана на прикладах бріофітів, що зростають на екскрементах та на прикладі епіфітних бріофітів. Охарактеризовано участь бріофітів в угрупованнях - диференціація по нішах, зразки співіснування, процеси регенерації і роль пошкоджень бріофітів, конкурентна здатність, взаємодія з вищими рослинами. Цікавий матеріал подає автор щодо видового багатства бріофітів на справжніх островах та на «клаптевих» субстратах - на деревах, валунах, гнилій деревині.

Автор підкреслює, що видовий склад і багатство в угрупованні залежить як від процесів в самих угрупованнях, так і від тих, що діють між угрупованнями, згідно з теоріями метапопуляційної біології та острівної біогеографії. Він використовує концептуальну модель про роль процесів, масштабно-залежних від складу бріофітів, і як вони відрізняються від складу судинних рослин, оскільки завдяки великій кількості дуже дрібних спор бріофіти менш обмежені у розсіюванні в масштабах континента, свідченням чого є велика подібність видового складу саме в масштабах континента. Крім того, автор підкреслює, що на рівні угруповання $\epsilon$ багато випадків співіснування нішевої диференціації і розподілу серед видів по мікромасшабних градієнтах навколишнього середовища. На думку автора, більш вражаючим $\epsilon$ наявність багатьох екосистем 3 домінуванням бріофітів, в яких тісно співіснують кілька видів 3 подібною морфологією і історією життя - вони можуть конкурувати, але симетрична природа взаємодій робить конкурентне виключення дуже повільним процесом. Для бріофітів, як підкреслює автор, дуже важливим для видового багатства і формування складу угруповання є дрібномасштабні порушення і постійне утворення місць 3 порушеними субстратами, на яких поселяються багато видів.

\section{1. Види та видоутворення у бріофітів.}

Jonathan Shaw (Duke University, Durham, USA)

Автор аргументовано показує, що бріофіти - мохи, печіночники та антоцеротові $\epsilon$ успішними групами ранніх ембріофітів: видовий склад мохів становить близько 13000 видів, печіночників - біля 5000 і антоцеротофітів - близько 150 видів, тобто бріофіти поступаються за видовим складом лише покритонасінним. За твердженнями автора, кількісний аналіз не підтвердив відомих вказівок про те, що бріофіти мають найбагатший видовий склад в тропіках і $є$ прикладом організмів, які збільшують свій видовий склад в напрямку екватора; різноманіття печіночників (за деяким винятком, наприклад, родина - Lejeneaceae) найбільше від помірних до високих широт південної півкулі.

На думку автора розділу, видів викопних бріофітів ще дуже мало, щоб оцінити, чи були ці групи більш-менш різними в геологічному минулому, адже багато ранньотретинних і навіть старіших бріофітів виглядають однаково з таксонами, що збереглися нині, і такі пояснення посприяли погляду, що багато чи більшість бріофітів лише трішки змінилися за 
величезний проміжок часу (десятки мільйонів років) і повинні розглядатися як «живі викопні». Автор вважає, що заява Крама (Crum, 1972) про те, що мохи - це «незмінні і нерухомі сфінкси минулого», які еволюційно не спроможні, але добре адаптовані до сучасної ролі в природі» - одна 3 часто цитованих спекуляцій в літературі $з$ еволюційної біології бріофітів. Підтвердженням цієї думки автора $\epsilon$ те, що більшість бріофітів дуже відрізняються на генетичному рівні, спостерігається екотопічна диференціація серед популяцій деяких видів бріофітів, $\epsilon$ інтерспецифічні еволюційні моделі, які включають приховане видоутворення, гібридизацію і алополіплоідію; ступінь нуклеотидного заміщення у ядрі, хлоропластах, мітохондріях при порівнянні (стосовно філогенії) була нижчою у мохів, ніж у насінних рослин. Проте автор вказує на винятки, існує систематична i філогенетична очевидність, що деякі групи бріофітів зазнали періодів швидкої диверсифікації, наприклад, родина Lejeneaceae, а взагалі ступінь появи нових видів у бріофітів оцінюється величиною $0,56( \pm 0,004)$ на 1 млн. років, що $\epsilon$ швидшим порівняно 3 оцінками швидкої радіації у покритонасінних.

Автор вказує, що, грунтуючись на філогенії, оцінці викопних бріофітів та калібровці за часом, бріологами встановлено дату виникнення плеврокарпних мохів, це - 194-161 млн років, а диверсифікація головних предків мохів плеврокарпних родин - 165-131 млн. років; їх калібрована філогенія припускала, що багато родин мохів виникли в крейдяному періоді, більше 100 млн. років тому, але точність датування для бріофітів лімітується нестачею хороших каліброваних викопних решток.

Щодо печіночників, то у розділі вказується, що Jungermanniopsida диверсифікувалися із Marchantiopsida (комплекс таломних печіночників) приблизно 370 млн. років тому в пізньому девоні, а листостеблові і прості таломні предки з'явилися 310 млн. років тому, у пізньому карбоні. Дані оцінки дали привід автору розділу допустити, що багато родин бріофітів дуже давні, хоча ми ще мало знаємо про вік видів, що збереглися до цього часу - морфологічно приховані види і алополіплоїди відомі як для мохів, так і для печіночників, що свідчить про недавні дивергенцію і видоутворення, проте генетичні моделі у деяких алополіплоїдів припускають їх дуже давнє походження.

У розділі також наводяться видові концепції, морфологічні дефініції, біологічні і філогенетичні концепції виду, делімітація видів бріофітів, заснована на молекулярних маркерах, механізми видоутворення у бріофітів, алополіплоїди у печінчників і мохів, темпи i режими алополіплоїдної еволюції. В узгоджених еволюційних висновках видових концепцій, обгрунтованих на молекулярних даних, автор вказує, що суперечки щодо біологічної або філогенетичної концепції виду $є$ деякою мірою штучними: еволюційні біологи сконцентрувалися на механізмах видоутворення і віддають перевагу концепції біологічних видів, інші ж, що концентруються на визначенні і розмежуванні видів, віддають перевагу філогенетичній концепції. Автор особливо підкреслює, що алополіплоїди становлять особливу проблему для таксономії, адже розпізнавати алополіплоїди як види $є$ стандартною практикою, навіть тоді, коли відомо, що вони поліфілетики, а практика також йде врозріз з концепцією філогенетичних видів, яка вимагає монофілії. На думку автора, альтернативою буде розпізнати два, три..., десять або більше монофілетичних видів, які не можуть бути визначені морфологічно, і які в деяких випадках функціонують разом як «еволюційно значимі одиниці». Молекулярний підхід до вивчення поліплоїдних утворень уточнив деякі аспекти еволюції бріофітів, але можливо, як образно пише автор, «забруднив води» таксономії бріофітів.

\section{2. Біологія охорони бріофітів.}

Alain Vanderpoorten and Tomas Hallingbäck (University de Liege, Belgium; Swedish University of Agricultural Sciences, Sweden)

У розділі обговорюється статус біології охорони бріофітів, вказується, що це фактично нова, багатодисциплінарна наука, завданням якої було ліквідувати кризу, з якою зіткнулося біорізноманіття - як кризова дисципліна, біологія охорони була відповіддю на 
політичні вимоги сміливо зустріти драматичну втрату біорізноманіття і прийняти відповідні заходи, щоб передбачити та попередити і повернути назад цю тенденцію. Автори вказують, що послідовна ратифікація Конвенції з біорізноманіття на конференції ООН в Ріо у 1992 р. більшістю урядів країн світу чітко поставила предмет біорізноманіття на політичний порядок денний, а кілька минулих років показали значну еволюцію у розумінні охорони. $€$ вже розуміння, підкреслюють автори розділу, що необхідно включити в програми охорони спорові взагалі і бріофіти зокрема. На думку авторів, причини пізнього, але нині зростаючого інтересу до охорони бріофітів різноманітні: бріофіти рідко $є$ помітними елементами ландшафту, але вони відіграють важливу екологічну роль 3 точки зору водного балансу, контролю ерозії, ресурсів азоту або просто забезпечення місцезростання для інших організмів, більше того, бріофіти локально представляють собою такий рівень видового різноманіття, яке можна порівняти з покритонасінними або навіть і вище.

У розділі розглядаються інструменти, доступні для оцінки рівня загрози бріофітам, зокрема, як класифікаця МСОП може бути використана для охорони бріофітів, що забезпечило законодавчу охорону зникаючих видів і їх місцезростань. Розглядаються рівні та механізми загроз для бріофітів та необхідність охорони бріофітів, а також стратегії для збереження бріофітів. Підкреслюється, що практичні інструменти виконання, стають доступними для створення мереж охоронних зон для бріофітів і управління ними, а також розробляються багатообіцяючі нові методи їх охорони ex situ. Автори звертають увагу, що йде дискусія про те, які ж види треба охороняти, адже види не еквівалентні за «цінністю біорізноманіття», оскільки крім відмінностей у рідкісності та рівні загроз, вони відрізняються філогенетичною історією і процесами, що протікають у популяціях. Автори вказують, що молекулярні дослідження розкрили вражаючі внутрішньовидові рівні генетичної варіації, які відрізняються від морфовиду, наприклад, бріологами знайдено, що у Sphagnum морфологічно визначені види нееквівалентні відносно молекулярного біорізноманіття, оскільки морфовиди відрізняються рівнями здійснюваного ними нуклеотидного варіювання та ступенем їх філогенетичного відмежування від близькоспоріднених видів. Робиться наголос, що постає питання, на яке непросто дати відповідь, а саме, що цінніше, що краще зберігати - роди або криптичні види усередині генетичного варіюючого, але морфологічно однорідного таксона, чи деякі рідкісні, але однорідні види, що близько споріднені зі звичайними видами. У розділі робиться наголос на те, що еволюційний підхід до біорізноманіття, який може бути доповнений, можливо, замінить традиційний підхід, сфокусований на рівнях загрози і на концепції фенетичних видів.

На закінчення треба відзначити, що дана книга видрукувана (видавництво Cambridge University Press, $U K$ ) на високому поліграфічному рівні, хороший шрифт, легко читається, кожний розділ в міру насичений необхідними ілюстраціями - рисунками, таблицями, діаграмами, графіками. У кінці кожного розділу наведено список використаної літератури, який, як правило, включає повний перелік основних наукових публікацій з даної проблеми, що надруковані у відомих наукових, головним чином англомовних виданнях. На жаль, у книзі практично зовсім не враховане наукове надбання у дослідженні мохоподібних вченими України та багатьох інших східноєвропейських країн. Очевидно головною перешкодою $\epsilon$ мовна проблема, цьому підтвердженням $\epsilon$ те, що автор 5-го розділу даної праці Andrew.C.Cuming (Leeds University, UK), вказав, що причиною тривалого невикористання матеріалів з генетики та біології розвитку початку XX ст. були труднощі для англофонного наукового співтовариства у розумінні цих праць, оскільки вони написані латиною та формалізованою німецькою мовою. Проте, у контексті триматися у дослідженнях бріології і біології на рівні розвинутих країн, дуже бажано було б перекласти рецензовану працю українською мовою та видрукувати відповідним накладом, щоб вона була доступна, як науковцям, так і студентам та викладачам біології вищої школи. 